\title{
Comparative Studies on the Electrical and Mechanical Behavior of Some Soldering and / or Impregnation Lacquers
}

\author{
ADRIANA-MARIANA BORS' ${ }^{1}$, DANIEL LINGVAY2, ALINA-RUXANDRA CARAMITU ${ }^{3 *}$, IULIAN IORDACHE ${ }^{3}$, IOSIF LINGVAY ${ }^{3}$ \\ 1.ICPE SA, 313 Splaiul Unirii, 030138, Bucharest, Romania \\ 2.Sapientia Hungarian University of Transylvania, Faculty of Sciences and Arts, 4 Calea Turzii , 400193, Cluj-Napoca, Romania \\ 3.National Institute for Research and Development in Electrical Engineering INCDIE ICPE-CA, 313, Splaiul Unirii, 030138, Bucharest, \\ Romania
}

\begin{abstract}
In order to evaluate the behavior in various electrical applications, the main mechanical and electrical characteristics of three different varieties of specifically chosen lacquers - based on alkyl-epoxy-melamine copolymer, the epoxy polymer and polyurethane were compared. From the mechanical determinations, it was found that at ambient temperature the polyurethane lacquer bending resistance was approximately equal to that of the epoxy lacquer and about 6.5 times higher that of the alkyl-epoxy-melamine copolymer. It has also been shown that at bending force of less than $150 \mathrm{Nm}$ the investigated polyurethane lacquer has relatively large deformations of $0.4 \mathrm{~mm} / \mathrm{kN}$, which indicates a high capacity to take over relatively high deformations of the metal support (due to thermal expansion from various applications) without significant increasing mechanical stress. The recorded values for the alkyl-epoxy-melamine-based copolymer lacquer and the pure epoxy lacquer are $0.11 \mathrm{~mm} / \mathrm{kN}$ and $0.03 \mathrm{~mm} / \mathrm{kN}$ respectively. Determinations by dielectric spectroscopy have shown that at frequencies below $250 \mathrm{~Hz}$ the dielectric losses tg $\delta$ for the epoxy and polyurethane lacquers are approximately equal and are about 2.9 times lower than for the alkyl-epoxymelamine copolymer lacquer. It was also found that at frequencies higher than $250 \mathrm{~Hz}$ the investigated materials behave differently, respectively at the frequency increase up to $10 \mathrm{kHz}$, the dielectric loss tg $\delta$ of the polyurethane lacquer remains constant at about 0.0045 in contrast to the epoxide lacquer at which the dielectric loss tg $\delta$ increases monotone to 0.0095 at $10 \mathrm{kHz}$, respectively of the alkyl-epoxy-melamine copolymer at which the dielectric loss tg $\delta$ is approximately constant 0.012 in the $250 \mathrm{~Hz}-10 \mathrm{kHz}$ range.
\end{abstract}

Key words: lacquers, dielectric loss, resistivity, bending force, hardness

The lacquers are synthetic polymeric materials (epoxy [1-5], acrylic [6-8], ester [9,10], polyurethane [11] etc.) or natural (plant extracts such as Urushi $[12,13]$, insect secretion - Shellac $[14,15])$.

Depending on the type of polymer, ingredients, polymerization conditions, etc. the physical-chemical characteristics of the lacquers are different and have multiple uses in the most diverse fields such as the furniture industry, coatings for protection, pharmaceutical industry, electrical engineering, etc.

Obtaining precursors (monomers, hardeners, plasticizers, etc.) of synthetic lacquers is accomplished by industrial processes with significant environmental risk [16] - especially air dispersion (especially vapours) of various persistent emissions [17-21].

On the other hand, both waste resulting from the application of synthetic lacquers and end-of-life waste products containing polymer and / or synthetic lacquer coatings are hardly biodegradable - they have a pronounced resistance to the moulds action [22-25].

The electrical and mechanical characteristics of polymers and composite polymer materials are determined by the nature of the polymer and the filler as well as by the polymerization conditions [26-31].
In electrical applications, lacquers are used to impregnate windings of motors and transformers, fix magnets etc. - applications where the electrical characteristics (resistivity, dielectric losses, breakthrough voltage, etc.) and mechanical characteristics (breaking strength, elasticity, hardness, etc.) are determinant/ decisive.

When using at impregnating of windings power transformers with mixed insulation, it is necessary that the lacquer be compatible with the used electro-insulating fluid, and not degrade or initiate chemical degradation processes of the electro-insulating fluid [32-37].

In view of these considerations, the purpose of the paper is to compare the electrical and mechanical behaviour of some lacquers from class $\mathrm{H}$, used for soldering / impregnating some component parts (benchmarks: stator, rotor) of the electric servo motors.

\section{Experimental part}

By electrical and mechanical measurements three different types of lacquers were compared. The types of investigated lacquers, which were chosen according to the class of insulation, $\mathrm{F}\left(155^{\circ} \mathrm{C}\right), \mathrm{H}\left(180^{\circ} \mathrm{C}\right)$ and $\mathrm{C}$ (above $180^{\circ} \mathrm{C}$ ) are shown in table 1.

Table 1

THE TYPES OF LACQUERS INVESTIGATED

\begin{tabular}{|c|c|c|c|}
\hline $\begin{array}{c}\text { Sample } \\
\text { Code }\end{array}$ & Type of lacquer & Structure & Solvent \\
\hline$L-528$ & 528 EZ [38] & monocomponent alkyl-epoxy-melamine & $\begin{array}{c}\text { Thinner 528 EZ - a mixture of aromatic hydrocarbons } \\
\text { and alcohols. }\end{array}$ \\
\hline$L-G$ & ROPOXID 501 [39] & Bicomponent - epoxy & Acetone \\
\hline$L-S$ & $\begin{array}{c}\text { SIGMADUR } \\
\text { CLEARCOAT [11] }\end{array}$ & bicomponent - polyurethane & $\begin{array}{c}\text { Thinner 21-06 a mixture of aromatic hydrocarbons } \\
\text { and alcohols }\end{array}$ \\
\hline
\end{tabular}

\footnotetext{
*email: alina.caramitu@icpe-ca.ro, phone: + 40747116044
} 
For electrical determinations (dielectric spectroscopy and resistivity), samples were prepared on a cold-rolled silica sheet having the dimensions of $60 \times 200 \mathrm{~mm}$ and a thickness of $0.35 \mathrm{~mm}$ by immersion in the investigated lacquer.

After the leakage of excess lacquer (storage at $22 \pm$ $3^{\circ} \mathrm{C}$ for $2 \mathrm{~h}$ ) the polymerization of lacquer was achieved by heat treatment - heating with 1.5 degrees / minute and after 3 hours at $155 \pm 5^{\circ} \mathrm{C}$, natural cooling in the oven with thermostat and air circulation.

The thicknesses of lacquer layers obtained - measured with a micrometer - were in the $35 \pm 4 \mu \mathrm{m}$ range.

For the breaking strength determination, samples were made by bonding two pieces of square steel bar of $22 \times 22$ $\mathrm{mm}$ with the investigated lacquers.

The polymerization of lacquer from samples achieved was made at $155 \pm 5^{\circ} \mathrm{C}$ for $3 \mathrm{~h}$. The image of the samples used to determine the bending strength and their positioning on the test machine is shown in figure 1.

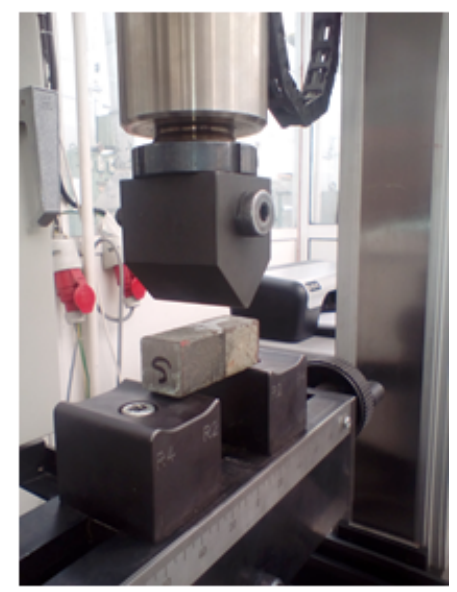

Fig. 1. Image of the samples used to determine the breaking strength by bending

Bending strength determinations were made on walter+bai ag Testing Machines device, model LFM 30 kN, Switzerland (www.walterbai.com).

Type of mechanical tests including compression strength - three-point bending strength at the maximum strength of $30 \mathrm{kN}$ and measurement accuracy of $0.5 \%$ at ambient temperature $\left(22 \pm 3^{\circ} \mathrm{C}\right)$.

Dielectric spectroscopic determinations of dielectric losses $\operatorname{tg} \delta$ were performed at ambient temperature (22 $\pm 3{ }^{\circ} \mathrm{C}$ ) on AMTEK - 1296 Dielectric interface Solartron Analytical equipment.

The electrical resistivity of the lacquers was calculated from the resistance values measured at ambient temperature $\left(22 \pm 3{ }^{\circ} \mathrm{C}\right)$ with FLUKE 1550B Mega Ohm Meter. Measurements were performed in DC at $250 \mathrm{~V}$ with a circular measuring electrode described in $[40,41]$ having a contact surface of $20 \mathrm{~cm}^{2}$.

Three samples with different coating thicknesses were measured for each type of lacquer. Shore hardness determinations were made at ambient temperature ( $22 \pm$ $3^{\circ} \mathrm{C}$ ) with Shore A, model HBA 100_0, manufactured by SAUTER (Germany).

\section{Results and discussions}

The results of the Shore hardness determinations are shown in table 2.

Table 2

RESULTS OF SHORE HARDNESS DETERMINATIONS

\begin{tabular}{|c|c|}
\hline Sample code & Shore A hardness \\
\hline$L-528$ & $50-60$ \\
\hline$L-G$ & $63-69$ \\
\hline$L-S$ & $87-98$ \\
\hline
\end{tabular}

By analyzing the values in table 2 it is found that the hardness of $\boldsymbol{L}$-S lacquer is systematically higher than that of $\boldsymbol{L}-\boldsymbol{G}$ lacquer (by about $40 \%$ ) and that of $\boldsymbol{L}-\mathbf{5 2 8}$ lacquer (by about $67 \%$ ).

In figure 2 shows the bending force and deformation diagrams, obtained on the investigated samples (by continuous deformation and bending force monitoring) placed on supports with a distance of $2 \mathrm{~cm}$ between them.

In figure 2, it is noted that the three investigated materials (3 types of lacquers) respond differently to the bending force. Thus, for $L-528$ lacquer, when increasing the bending force, the deformation increases monotonously (with an average value of about $0.11 \mathrm{~mm} / \mathrm{kN}$ ), up to a critical value when the material breaks (at about $1350 \mathrm{~N}$ ).

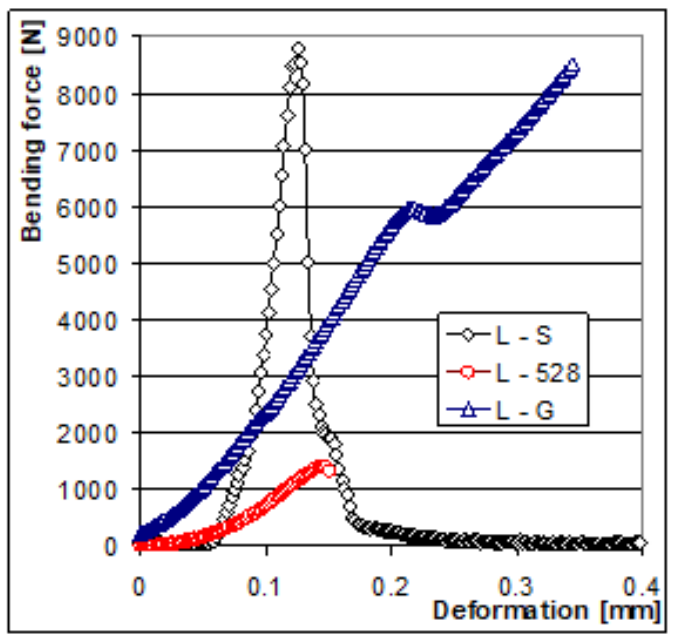

Fig. 2. Bending force and deformation diagrams obtained on investigated samples

For $\mathbf{L}-\mathbf{G}$ lacquer, at increasing bending force, the deformation is monotonous (about $0.03 \mathrm{~mm} / \mathrm{kN}$ ) up to a value of about $6000 \mathrm{~N}$ when, a level of deformation occurs more pronounced (suggesting a flow of the lacquer, a slight elasticity, respectively), after which, until the material breaks (at about $8500 \mathrm{~N}$ ) the increase of the deformation is approximately linear $0.04 \mathrm{~mm} / \mathrm{kN}$ ).

The $L$-S lacquer, shows a particular behavior namely, up to about $150 \mathrm{~N}$ is recorded a relatively large deformation of $0.06 \mathrm{~mm}$ (about $0.4 \mathrm{~mm} / \mathrm{kN}$ ), after which up to $8800 \mathrm{~N}$ the deformation is relatively small $(0.01 \mathrm{~mm} / \mathrm{kN})$ followed by a marked of flow area with large deformation at the decrease bending force $(-0.032 \mathrm{~mm} / \mathrm{kN})$ up to about $50 \mathrm{~N}$ when the material breaks.

This behavior of the $\boldsymbol{L}$-S lacquer indicates that in electrical applications it is capable of taking over relatively high deformations of the metal support (due to thermal expansion) without significant increasing the mechanical stress of the insulation system.

Scheme in figure 3 , shows the parameters for the calculation of the bending resistance $\sigma_{b}$, of the investigated materials.
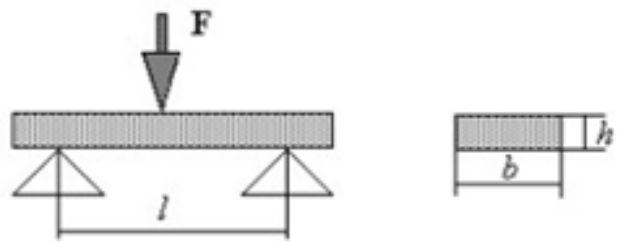

Fig. 3. Scheme for calculating bending resistance and bending resistance module: where:

F - applied force (maximum values); I - distance between supports; $\mathrm{b}$ - sample width; $\mathrm{h}$ - the height of the sample 
With the notations in figure $3, \sigma_{b}$, is:

$$
\sigma_{b}=\frac{M_{b}}{W}=\frac{3 \cdot F_{\max } \cdot l}{2 \cdot b \cdot h^{2}}
$$

where:

$M_{b}$ - bending moment; $F_{\max }$ - the maximum value of bending force;

W - bending resistance module;

$$
\begin{array}{r}
M_{b}=\frac{F_{\operatorname{maxx}} \cdot l}{4} \\
W=\frac{b \cdot h^{2}}{6}
\end{array}
$$

The calculated values of $\sigma$ and $W$ for the investigated samples $(I=2 \mathrm{~cm} ; b=h=2.2 \mathrm{~cm})$ are shown in table 3 .

\section{Table 3}

BENDING RESISTANCE $\sigma_{b}$ OF THE INVESTIGATED SAMPLES

\begin{tabular}{|c|c|}
\hline Sample code & Bending resistance, $\sigma b\left[\mathbf{N} / \mathrm{cm}^{2}\right]$ \\
\hline$L-528$ & 190 \\
\hline$L-G$ & 1197 \\
\hline$L-S$ & 1239 \\
\hline
\end{tabular}

By analyzing the values in table 3 it is found that at the ambient temperature the $\boldsymbol{L}-\boldsymbol{S}$ lacquer bending resistance is approximately equal to that of $L-G$ lacquer and about 6.5 times higher than that of $\mathbf{L}-\mathbf{5 2 8}$ lacquer.

Results of determination by the dielectric spectroscopy technique and respectively, evolutions of dielectric loss and of frequency, are comparatively presented in figure 4.

By analyzing figure 4 , it is observed that at the ambient temperature and at frequencies up to $250 \mathrm{~Hz}$ there are no differences in the dielectric behavior of the $\mathbf{L}-\mathbf{G}$ and $\mathbf{L}-\boldsymbol{S}$ lacquers, but as the frequency increases, dielectric loss $\operatorname{tg} \delta$ for the $L-G$ lacquer have a tendency of continues growth up to about 0.0098 , compared to L-S lacquer, which up to $10 \mathrm{kHz}$ has a dielectric loss tg $\delta$ approximately constant of 0.0045 .

As it can be seen in figure 4, at frequencies higher than $2 \mathrm{kHz}$, dielectric loss $\operatorname{tg} \delta$ for $\mathbf{L}$-S lacquer is less about twice compared to $L-G$ lacquer and about 2.6 times with the $L$ 528 lacquer. It is also noted that, at frequencies up to 250 $\mathrm{Hz}$ dielectric losses, $\operatorname{tg} \delta$ for $\mathbf{L - 5 2 8}$ lacquer are about 2.9 times higher than for $\boldsymbol{L}-\boldsymbol{G}$ and $\boldsymbol{L}-\boldsymbol{S}$ lacquers.

These $\operatorname{tg} \delta$ dielectric losses values indicate that for electric motors the heating due to dielectric losses in insulation can be substantially smaller (up to 2.9 times) when using the $\mathbf{L}-\mathbf{S}$ or $\mathbf{L}-\mathbf{G}$ lacquers for the windings consolidation compared to $L-528$ lacquer, with the remark that, $\mathbf{L}-\boldsymbol{S}$ lacquer has dielectric losses tg $\delta$ of only 0.0045 including at frequencies in the $250 \mathrm{~Hz}$ to $10 \mathrm{kHz}$ range.

The volume resistivity calculation ñ, for the investigated lacquers was performed with the relation (4):

$$
\rho=R \cdot \frac{S}{d}
$$

where:

$\mathrm{R}$ - measured insulation resistance; $\mathrm{S}$ - area of the measuring probe $\left(20 \mathrm{~cm}^{2}\right)$;

$d$ - thickness of the insulation layer (lacquer).

The measured values of $\boldsymbol{R}$ at ambient temperature and the calculated values of $\boldsymbol{\rho}$ are comparatively presented in table 4.

By comparing the data presented in table 4 , it is observed that the volume resistivity of the $\boldsymbol{L}-\boldsymbol{S}$ lacquer is about $10 \%$ higher than for the $\mathbf{L - G}$ lacquer and about 3.6 times higher than for the $\mathbf{L} \mathbf{- 5 2 8}$ lacquer, values that are consistent and explain the evolution of the dielectric losses at low frequencies (up to $250 \mathrm{~Hz}$ ) of the lacquers (the contact area $\boldsymbol{S}$ for all samples was of $20 \mathrm{~cm}^{2}$ ).

\begin{tabular}{|c|c|c|c|}
\hline $\begin{array}{c}\text { Sample } \\
\text { code }\end{array}$ & $\begin{array}{c}\text { Layer thickness } \\
d[\mathrm{~mm}]\end{array}$ & $\begin{array}{c}\text { Measured resistance } \\
R \text { [G } \Omega]\end{array}$ & $\begin{array}{l}\text { Volume resistivity } \\
\rho[\Omega \cdot \mathrm{cm}] \times 10^{15}\end{array}$ \\
\hline \multirow{4}{*}{$L-528$} & & & \\
\hline & 0.031 & 3.4 & 22.0 \\
\hline & 0.034 & 3.5 & 20.9 \\
\hline & 0.038 & 3.6 & 19.1 \\
\hline & & & \\
\hline \multirow{3}{*}{$L-G$} & 0.037 & 12.1 & 65.6 \\
\hline & 0.033 & 11.9 & 72.4 \\
\hline & 0.035 & 12.2 & 69.8 \\
\hline & & & \\
\hline \multirow{3}{*}{$\boldsymbol{L}-\boldsymbol{S}$} & 0.036 & 13.3 & 74.2 \\
\hline & 0.033 & 12.9 & 78.4 \\
\hline & 0.035 & 13.1 & 75.1 \\
\hline
\end{tabular}

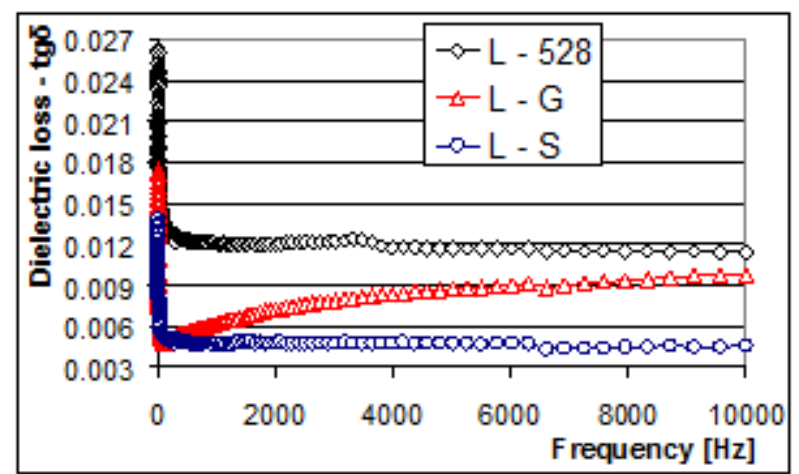

Fig. 4. Evolution of dielectric loss tgd vs frequency of investigated lacquers

Table 4

VOLUME RESISTIVITY OF INVESTIGATED LACQUERS

\section{Conclusions}

Three different types of lacquers based on alkyl-epoxymelamine copolymer ( $\boldsymbol{L}-\mathbf{5 2 8})$, epoxy polymer ( $\boldsymbol{L}-\boldsymbol{G})$ and polyurethane $(\boldsymbol{L}-\boldsymbol{S})$ have been characterized by mechanical (bending resistance and Shore A hardness) and electrical (dielectric spectroscopy - dielectric losses and insulation resistance in $\mathrm{DC}$ ) determinations.

The main conclusions after processing the experimental results are:

-the polyurethane-based lacquer has relatively large deformations of approx. $0.4 \mathrm{~mm} / \mathrm{kN}$ up to $150 \mathrm{~N}$ bending 
force, so it has the ability to take over relatively high deformations of metal support (due to thermal expansion from various applications) without significant increase of the mechanical stress, unlike the alkyl-epoxy-melamine based copolymer lacquer $(0.11 \mathrm{~mm} / \mathrm{kN})$ and the pure epoxy lacquer $(0.03 \mathrm{~mm} / \mathrm{kN})$;

-at ambient temperature the bending resistance of the $\boldsymbol{L}-\boldsymbol{S}$ polyurethane lacquer is about equal to that of the $\mathbf{L}-\boldsymbol{G}$ epoxy lacquer and about 6.5 times greater than that of the L-528 alkyl-epoxy-melamine - based copolymer lacquer; -at frequencies below $250 \mathrm{~Hz}$ the dielectric losses in the epoxy and polyurethane lacquers are about equal and are about 2.9 times lower than in the alkyl-epoxy-melamine copolymer lacquer;

-at frequencies higher than $250 \mathrm{~Hz}$ the investigated lacquers behave differently, namely at the frequency increase up to $10 \mathrm{kHz}$, the dielectric loss $\operatorname{tg} \delta$ of the polyurethane lacquer remains constant at about 0.0045 , unlike the epoxide lacquer at which dielectric loss $\operatorname{tg} \delta$ increases monotone up to 0.0095 at $10 \mathrm{kHz}$, or for the alkylepoxy-melamine-based copolymer lacquer at which the $\operatorname{tg} \delta$ is about constant 0.012 in the $250 \mathrm{~Hz}-10 \mathrm{kHz}$ range;

-the resistivity of the polyurethane $\boldsymbol{L}-\boldsymbol{S}$ lacquer is about $10 \%$ higher than the $L-G$ epoxylacquer and about 3.6 times higher than the $\mathbf{L}-\mathbf{5 2 8}$ alkyl-epoxy-melamine-based copolymer lacquer.

Acknowledgment: The authors thank for funding by the contract type D, No.11384/18.06.2018 (ECO-NANO-ECO) and project Nucleu No. Xxxxx/2019 for access to the objective and logistical support in carrying out the work; contract 30PFE/2018 (between National R\&D Institute for Electrical Engineering ICPE-CA and Romanian Ministry of Research and Innovation - MCl)

\section{References}

1. RUS, T., BORS, A.-M., CARAMITU, A.-R., LINGVAY, I., VAIREANU, D.I., Mat. Plast., 55, no. 2, 2018, p. 167.

2.BRIA, V., MUNTENITA, C., GRAUR, I., Mat.Plast., 55, no. 3, 2018, p. 295.

3.LADANIUC, M.-A., HUBCA, G., GABOR, R., NICOLAE, C.-A., ALEXANDRESCU, E., SANDU T., Mat. Plast., 54, no.1, 2017, p. 125. 4.MUNTENITA, C., BRIA, V., ENI, C., CIRCIUMARU, A., GRAUR I., Mat. Plast., 53, no.3, 2016, p. 509.

5.LADANIUC, M.-A., HUBCA, G., GABOR, R., NICOLAE, C.-A., SANDU T., Mat. Plast., 52, no.4, 2015, p. 433.

6.SIPOS, S., BARAC, B., MALITA, I., Mat. Plast., 55, no.1, 2018, p.111. 7.ROMANEC, C., STAN, C.-I., HINGANU, M.-V., SCUTARIU, M.-M., ROSU, S., HINGANU, D., Rev. Chim. (Bucharest), 69, no. 11, 2018. p. 4052. 8. ANDREESCU, C.-F., GHERGIC, D.-L., BANATEANU, A.-M., BECHIR, A.-M., PATROI, D.-N., HANCU, V., Mat. Plast., 54, no.2, 2017, p. 244. 9.STEIGMANN, R., SAVIN, A., IFTIMIE, N., Mat. Plast., 55, no. 3, 2018, p. 410.

10.GAWDZINSKA, K., NABIALEK, M., BRYLL, K., SZYMANSKI, P., SANDU A.-V., Mat. Past. 54, no. 3, 2017, p. 539.

11. *** https://www.ppgpmc.com/Products/7531/SIGMADURCLEARCOAT.aspx

12. YANG, J., DENG, J., ZHU, J., LIU, W., ZHOU, M., LI, D., Progress in Organic Coatings, Vol. 94, 2016. p. 41.

13. ISHIMURA, T., YOSHIDA, T., International Journal of Polymer Science Volume, 2015, Article ID 782843, http://dx.doi.org/10.1155/2015/ 782843

14. SHARMA, S.-K., SHUKLA, S.-K., VAID, D.-N., Def. Sci. J., Vol. 33, No.3, 1983, p. 261.

15. PHAECHAMUD, T., PRAPHANWITTAYA, P., LAOTAWEESUB, $K_{\text {., }}$ Journal of Pharmaceutical Investigation, Vol. 48 (3), 2018, p. 409.
16.STERE, E.A., POPA, I., Electrotehnica, Electronica, Automatica (EEA), Vol. 66 (3), 2018, p. 125.

17. NEAMTU, S., BORS, A.-M., STEFAN, S., Rev. Chim. (Bucharest), 58, no. 9, 2007, p. 938.

18. BOR a , A.-M., CIUCULESCU, C.-A., MEGHEA, A., Rev. Chim. (Bucharest), 58, no. 2, 2007, p. 151.

19.BORS, A.-M., MEGHEA, A., NEAMTU, S., LESNIC, M., Mathematical model for persistent organic pollutants dispersion, Rev. Chim. (Bucharest), 58, no. 8, 2007, p. 776.

20. BORS, A.-M., MEGHEA, I., NICOLESCU, A.-M., BORS, A.-G., 12th International Multidisciplinary Scientific GeoConference and EXPO Modern Management of Mine Producing, Geology and Environmental Protection, SGEM 2012, Vol. 5, p. 891.

21. MEGHEA, I., BORS, A.-G., MUNTEANU, G.-V., MUNTEANU, C., BORS, A.-M, Updating implementation of European strategy in Romania regarding persistent organic pollutants, International Multidisciplinary Scientific GeoConference Surveying Geology and Mining Ecology Management, SGEM, 2013, Vol. 1, p. 1113.

22. AMMALA, A., BATEMAN, S., DEAN, K., PETINAKIS, E., SANGWAN, P., WONG, S., YUAN, Q., YU, L., PATRICK, C., LEONG, K.-H., Progress in Polymer Science, Vol. 36 (8), 2011. p. 1015.

23. RUS, T., RADU, E., LINGVAY, I., LINGVAY, M., CIOBOTEA-BARBU, O.-C., CAMPUREANU, C., BENGA, F.-M., LAZAR, G.-C., VAIREANU, D.I., U.P.B. Sci. Bull., Series B, Vol. 79, Iss. 4, 2017, pp. 167.

24. BORS, A.-M., BUTOI, N., CARAMITU, A.-R., MARINESCU, V., LINGVAY, I., Mat. Plast., 54, no. 3, 2017, p. 447.

25. CARAMITU, A., BUTOI, N., RUS, T., LUCHIAN, A.-M., MITREA, S., Mat. Plast., 54, no.2, 2017, p. 331.

26. SAVA, M., Mat. Plast., 53, no.3, 2016, p. 473.

27. HAMCIUC, C., HAMCIUC, E., BACOSCA, I., OLARIU, M., Mat. Plast., 47, no. 1, 2010, p. 11.

28. KUSNEROVA, M., VALIEEK, J., HARNIEAROVA, M., HALUZIKOVA, B., SKUBALA P., Mat. Plast., 51, no. 2, 2014, p.150.

29. NOTINGHER, P.-V., STANCU, C., ENESCU, I., Mat. Plast., 48, no. 2, 2011, p. 171.

30.NOTINGHER, P.-V., STANCU, C., ENESCU, I., ENESCU A., Mat. Plast., 47, no. 4, 2010, p. 393.

31. CARAMITU, A.-R., MITREA, S., MARINESCU, V., URSAN, G.-A., ARADOAIE, M., LINGVAY, I., Mat. Plast., 56, no. 1, 2019, p. 103

32. LINGVAY, I., RUS, T., BORS, A.-M., STANOI, V., UNGUREANU, L.-C., Electrotehnica, Electronica, Automatizari (EEA), Vol. 66 (3), 2018, p. 58.

33. LINGVAY, I., UNGUREANU, L.-C., STANOI, V., RUS, T., BORS, A.-M., SZATMARI, I., OPRINA, G., Electrotehnica, Electronica, Automatica (EEA), Vol. 65 (4), 2017, p. 117.

34. CUCOS, A., BUDRUGEAC, P., LINGVAY, I., BORS, A.-M., VOINA, A., Rev. Chim. (Bucharest), 69, no. 9, 2018, p. 2366.

35. LUNGULESCU, E.-M., LINGVAY, I., UNGUREANU, L.-C., RUS, T., BORS, A.-M., Mat. Plast., 55, no. 2, 2018, p. 201.

36. LINGVAY, I., BORS, A.-M., UNGUREANU, L.C., STANOI, V., RUS, T., Rev. Chim. (Bucharest), 69, no. 5, 2018, p. 1139.

37. RUS, T., CARAMITU, A.-R., UNGUREANU, L.-C., MARINESCU, V., BORS, A.-M., VAIREANU, D.-I., Mat. Plast., 55, no. 1, 2018, p. 28.

38.***http://www.cesivo.ro/Lac-de-impregnare/Lac-de-impregnareEZ528-4-Litri-372.html

39. STERE, E., POPA, I., BOTU, T.A., Electroinsulating epoxydic varninish for glass threads and production method, patent RO 100096 (B1) 12. 29. 1987

40. E., VARGA, L., FORTUNA, D., LINGVAY, A.-M. BORS, N.-O. (BUTOI) NICULA, LINGVAY, I., Mat. Plast., 55, no. 3, 2018, p. 320.

41. LINGVAY, I., FORTUNA, L., VARGA, E., BORS, A.-M., NICULA (BUTOI), N.-O., LINGVAY, D., Electrotehnic, Electronic, Automatizari (EEA), Vol. 66 (4), 2018, p. 52.

$\overline{\text { Manuscript received: } 15.12 .2018}$ 